\title{
Breast Cancer pNO(mol+) TNM Finding v8
}

National Cancer Institute

\section{Source}

National Cancer Institute. Breast Cancer pNO(mol+) TNM Finding v8. NCI Thesaurus.

Code C139432.

Breast cancer with positive molecular findings by reverse transcriptase polymerase chain reaction (RT-PCR); no ITCS detected. (from AJCC 8th Ed.) 